\title{
Digestibility and performance of lambs fed diets containing old man saltbush hay
}

\section{Digestibilidade e desempenho de cordeiros alimentados com dietas contendo feno de erva-sal}

\author{
Greicy Mitzi Bezerra Moreno ${ }^{1 *}$; Hirasilva Borba ${ }^{2}$; Gherman Garcia Leal de \\ Araújo $^{3}$; Tadeu Vinhas Voltolini ${ }^{3}$; Salete Alves de Moraes ${ }^{3}$; Américo Garcia da \\ Silva Sobrinho ${ }^{2}$; Oscar Boaventura Neto ${ }^{4}$; Dorgival Morais de Lima Júnior ${ }^{1}$; \\ Luís Gabriel Alves Cirne ${ }^{5}$; Marcos Eli Buzanskas ${ }^{6}$
}

\begin{abstract}
The aim of this study was to evaluate feed intake, digestibility, nitrogen balance, water balance, and performance of lambs fed diets containing old man saltbush hay associated with a concentrate. Thirtytwo castrated feedlot Santa Inês lambs at approximately eight months of age, with $22 \pm 1.97 \mathrm{~kg}$ body weight, were distributed into a completely randomized experimental design. Acid detergent fiber intake increased $(\mathrm{P}<0.05)$, whereas non-fibrous carbohydrates intake decreased $(\mathrm{P}<0.01)$. Inclusion of old man saltbush in the diet reduced $(\mathrm{P}<0.01)$ the digestibility of dry and organic matter, neutral and acid detergent fiber, and non-fibrous carbohydrates. The intakes of digestible dry and organic matter, ether extract, total carbohydrates, and digestible non-fibrous carbohydrates also decreased $(\mathrm{P}<0.01)$. Inclusion of old man saltbush did not influence water consumption from the trough by the sheep, averaging $4327.20 \mathrm{~mL} / \mathrm{day}^{-1}$. Body weight at slaughter and daily weight gain decreased linearly $(\mathrm{P}<$ 0.05 ) and feed conversion worsened as old man saltbush hay was added to the diet. Inclusion of old man saltbush at up to $40 \%$ replacing the concentrate in feedlot lamb diets does not compromise the performance of these animals.
\end{abstract}

Key words: Alternative feedstuff. Feedlot. Intake. Weight gain.

\section{Resumo}

Objetivou-se avaliar o consumo, digestibilidade, balanço de nitrogênio, balanço hídrico e o desempenho de cordeiros alimentados com dietas contendo feno de erva-sal associado a concentrado. Utilizou-se 32 cordeiros Santa Inês, castrados, com aproximadamente oito meses de idade, peso corporal de $22 \pm$ $1,97 \mathrm{~kg}$, distribuídos em delineamento experimental inteiramente casualizado. O consumo de fibra em detergente ácido aumentou $(\mathrm{P}<0,05)$, enquanto que o de carboidratos não fibrosos reduziu $(\mathrm{P}<0,01)$. A inclusão do feno de erva-sal na dieta dos animais reduziu $(\mathrm{P}<0,01)$ a digestibilidade da matéria seca e orgânica, extrato etéreo, fibra em detergente neutro e ácido e dos carboidratos não fibrosos. O consumo

\footnotetext{
${ }^{1}$ Profs. e Pesquisadores, Universidade Federal de Alagoas, UFAL, Arapiraca, AL, Brasil. E-mail: greicymitzimoreno@yahoo.com. br; juniorzootec@yahoo.com.br

${ }^{2}$ Profs. e Pesquisadores, Universidade Estadual Paulista, UNESP, Jaboticabal, SP, Brasil. E-mail: hiras@fcav.unesp.br; americo@ fcav.unesp.br

${ }^{3}$ Pesquisadores, Empresa Brasileira de Pesquisa Agropecuária, EMBRAPA, Petrolina, PE, Brasil. E-mail: gherman.araujo@ embrapa.br; tadeu.voltolini@cpatsa.com.br; salete.moraes@embrapa.br

${ }^{4}$ Prof. e Pesquisador, Universidade Federal de Alagoas, UFAL, Viçosa, AL, Brasil. E-mail: oscar_bn@yahoo.com.br

5 Prof. e Pesquisador, Universidade Federal do Oeste do Pará, UFOPA, Santarém, PA, Brasil. E-mail: lgabrielcirne@hotmail.com

${ }^{6}$ Prof. e Pesquisador da Universidade Federal da Paraíba, Areia, PB, Brasil. E-mail: marcosbuz@yahoo.com.br

* Author for correspondence
} 
de matéria seca e orgânica digestível, assim como o de extrato etéreo, carboidratos totais e não fibrosos digestíveis também reduziram $(\mathrm{P}<0,01)$. A inclusão da erva-sal não influenciou o consumo de água de bebida pelos ovinos com média de $4327,20 \mathrm{~mL} / \mathrm{dia}^{-1}$. O peso corporal ao abate e ganho de peso diário apresentaram comportamento linear negativo $(\mathrm{P}<0,05)$ e a conversão alimentar piorou com a inclusão do feno de erva-sal. A inclusão de feno de erva-sal em até $40 \%$ em substituição ao concentrado na dieta de cordeiros em confinamento não compromete o desempenho animal.

Palavras-chave: Alimento alternativo. Confinamento. Consumo. Ganho de peso.

\section{Introduction}

In view of the global warming that has been caused by climatic changes involved in the increased desertification and appearance of new arid and saline areas, producers and researchers have gained interest in plants resistant or tolerant to salinity and drought (halophytes and xerophytes) so that animal feeds can be produced in adverse soil (salinization) and climatic (low water availability) conditions (OTAL et al., 2010; ARAÚJO, 2011).

Old man saltbush (Atriplex nummularia Lindl.) is a forage shrub originating in Australia that has been used in many arid and semi-arid regions around the world as an important resource in the formulation of ruminant diets. This species is adapted to saline soils, and it can be productive and utilized in animal feeding where other forage species have not survived. The use of old man saltbush for sheep, goats, and cattle has been the object of studies of many researchers (SOUTO et al., 2004; BEN SALEM et al., 2005; ALVES et al., 2007; FRANCOTE et al., 2009); however, there are few studies investigating its use as an exclusive roughage source associated with concentrate feeds in the finishing of feedlot lambs.

The crude protein $(\mathrm{CP})$ of the leaves from the plant ranges between 10 and 17\% (FAO, 1996). At first, this is an interesting characteristic, as it renders this plant an energy source that can provide for feed scarcity periods. However, part of this nitrogen is non-protein and is associated with compounds such as nitrates, glycine, and proline, which reduce the rumen efficiency, and also with the acid detergent insoluble fiber, which is unavailable to the animal (VAN SOEST, 1994; McDONALD et al., 2002;
MEDEIROS; MARINO, 2015). Moreover, some antinutritional compounds like tannins, oxalates, saponins, and alkaloids are present and, in the rumen microflora, these are biotransformed into different compounds, forming intermediate or final substances. These substances, in turn, are absorbed by the gastrointestinal tract or eliminated in the feces, besides interfering with the use of protein and depressing digestion (AREGHEORE, 1999; AGUDELO, 2007).

Old man saltbush has a high mineral content in its composition (17.0 to $30.0 \% \mathrm{DM}$ ), and a great part of these minerals consist of sodium, chloride, and potassium. It also features high concentrations of calcium, magnesium, phosphorus, and sulfur, and some of these are present at contents greater than those recommended for ruminants (STANDING COMMITTEE ON AGRICULTURE, 1990).

Because of its high mineral content, the organic matter and metabolizable energy are low as compared with other herbaceous species, and the high concentration of salt also results in increased energy expenditure to the mineral metabolism and the maintenance of homeostasis (POTTER, 1961; ARIELI et al., 1989). This fact points to the need for supplementing old man saltbush with other sources of energy feedstuffs.

Diets composed of old man saltbush alone do not meet the nutritional requirements when aiming at high weight gains for finishing lambs. In this regard, the objective of this study was to evaluate the digestibility and performance of lambs fed diets containing old man saltbush associated with a concentrate. 


\section{Material and Methods}

The study was developed at Embrapa Semi-arid, in the municipality of Petrolina - PE, Brazil $\left(09^{\circ}\right.$ $23^{\prime} 55^{\prime}$ 'S latitude and $40^{\circ} 30^{\prime} 03$ " W longitude). The climate of the region is classified as a hot semiarid type (BSh type according to Köppen-Geiger's classification), with a spring-summer rainfall regime with an annual precipitation of $577 \mathrm{~mm}$ and $58 \%$ relative humidity of the air. During the experiment, the maximum, minimum, and average temperatures were 38,21 , and $29.4{ }^{\circ} \mathrm{C}$, respectively.

Thirty-two Santa Inês castrated lambs with an average initial weight of $22 \pm 1.97 \mathrm{~kg}$ and at eight months of age were used. At the beginning of the experiments, the animals were identified, dewormed, vaccinated against clostridial diseases, and distributed at random into the treatments. A period of 20 days of adaptation to experimental diets and facilities was adopted. Animals were housed in individual stalls equipped with feeder, drinker, and salt trough, located in an area covered by a shade net.

Treatments consisted of diets containing 30 , 40,50 , and $60 \%$ old man saltbush associated with a concentrate feedstuff, resulting in different roughage:concentrate ratios (Table 1). The concentrates were composed of ground corn, soybean meal, and urea, and diets were calculated to be isoproteic $(12.0 \% \mathrm{CP})$ and as stated by the NRC (2007) to meet the requirements of sheep with 20 kg body weight, aiming at a weight gain of $200 \mathrm{~g} /$ animal $/$ day $^{-1}$.

Table 1. Centesimal composition of ingredients and chemical-mineral composition of experimental diets.

\begin{tabular}{|c|c|c|c|c|}
\hline \multirow{2}{*}{ Composition } & \multicolumn{4}{|c|}{ Old man saltbush $\left(\mathrm{g} / \mathrm{kg}^{-1}\right)$} \\
\hline & 300 & 400 & 500 & 600 \\
\hline \multicolumn{5}{|l|}{$\overline{\text { Centesimal }\left(\mathrm{g} / \mathrm{kg}^{-1}\right)}$} \\
\hline Old man saltbush & 300 & 400 & 500 & 600 \\
\hline Ground corn & 591.50 & 495.00 & 399.00 & 303.00 \\
\hline Soybean meal & 96.00 & 96.00 & 96.00 & 96.00 \\
\hline Urea & 12.50 & 9.00 & 5.00 & 1.20 \\
\hline \multicolumn{5}{|l|}{ Chemical (DM basis, $\mathrm{g} / \mathrm{kg}^{-1}$ ) } \\
\hline Dry matter & 892.10 & 891.60 & 891.50 & 890.50 \\
\hline Organic matter & 928.10 & 913.30 & 898.50 & 883.70 \\
\hline Ash & 71.90 & 86.70 & 101.50 & 116.30 \\
\hline Crude protein & 125.70 & 124.60 & 123.50 & 122.30 \\
\hline Ether extract & 37.00 & 32.90 & 28.90 & 24.80 \\
\hline Neutral detergent fiber ${ }^{\mathrm{a}}$ & 317.70 & 358.90 & 400.20 & 441.50 \\
\hline Acid detergent fiber & 178.30 & 213.50 & 248.70 & 283.90 \\
\hline Lignin & 53.40 & 66.00 & 78.60 & 91.20 \\
\hline Total carbohydrates & 754.60 & 748.00 & 741.90 & 735.80 \\
\hline Non-fibrous carbohydrates & 436.90 & 389.10 & 341.70 & 294.20 \\
\hline Total digestible nutrients $\left(\mathrm{g} / \mathrm{kg}^{-1}\right)^{\mathrm{b}}$ & 711.80 & 682.50 & 604.00 & 564.10 \\
\hline Gross energy (Mcal/kg) & 4.23 & 4.15 & 4.07 & 3.99 \\
\hline \multicolumn{5}{|l|}{ Mineral (DM basis, $\left.\mathrm{g} / \mathrm{kg}^{-1}\right)$} \\
\hline Sodium & 18.80 & 24.90 & 31.00 & 37.10 \\
\hline Chloride & 22.80 & 30.20 & 37.80 & 45.20 \\
\hline Phosphorus & 6.20 & 6.00 & 5.80 & 5.70 \\
\hline Calcium & 3.40 & 4.10 & 4.70 & 5.40 \\
\hline Magnesium & 2.20 & 2.40 & 2.70 & 2.90 \\
\hline Potassium & 11.50 & 12.20 & 12.80 & 13.40 \\
\hline
\end{tabular}

${ }^{a}$ Neutral detergent fiber corrected for ash and protein. ${ }^{\mathrm{b}}$ Total digestible nutrients, calculated according to WEISS (1999), where $\mathrm{TDN}=$ digestible $\mathrm{CP}+2.25 \times$ digestible $\mathrm{EE}+$ digestible NDFap + digestible NFC. 
The old man saltbush plants originated from a 3-year-old field, grown in a soil classified as a plinthic Ultisol. Plots were irrigated only with the water resulting from the process of desalination with electrical conductivity of $11.00 \mathrm{dS} / \mathrm{m}$, used as a culture medium for pink tilapia (Oriochromis spp.). The water was delivered by a gated pipe. For haymaking, the old man saltbush plants were chopped and ground before being exposed to the sun, laid on a cemented area, and stirred twice daily. After three days, when they were dry to the touch, they were bagged. Leaves and fine- and medium- thickness (approximately $1.0 \mathrm{~cm}$ ) branches were used for haymaking.

The feed was supplied at $09 \mathrm{~h} 00$ and 16h00, with daily control of the amount provided, allowing for $20 \%$ as leftovers. During the feedlot period, samples of the ingredients (Table 2) and of the feeds supplied and leftovers were collected for laboratory analyses and determination of dry matter (DM) intake and feed conversion (calculated as the ratio between DM intake and daily weight gain). A feedlot period of 60 days was adopted, with the animals weighed at the start (initial weight) and end (final weight) of the experiment.

Table 2. Mineral and chemical composition of the ingredients of the experimental diets.

\begin{tabular}{lccc}
\hline \multirow{2}{*}{ Nutrient } & \multicolumn{3}{c}{ Ingredient $\left(\mathrm{g} / \mathrm{kg}^{-1}\right)$} \\
\cline { 2 - 4 } & Old man saltbush & Ground corn & Soybean meal \\
\hline Dry matter & 896.00 & 875.1 & 893.50 \\
Organic matter & 829.10 & 976.8 & 930.20 \\
Ash & 170.90 & 23.2 & 69.80 \\
Crude protein & 77.20 & 89.1 & 509.40 \\
Ether extract & 12.60 & 53.8 & 8.80 \\
Neutral detergent fiber & 650.50 & 256.8 & 288.00 \\
NDFap & 598.40 & 193.0 & 250.00 \\
Acid detergent fiber & 418.40 & 66.9 & 130.20 \\
Cellulose & 277.10 & 51.4 & 112.30 \\
Hemicellulose & 232.10 & 189.9 & 157.80 \\
Lignin & 141.30 & 15.4 & 17.90 \\
Total carbohydrates & 739.30 & 833.9 & 412.00 \\
Non-fibrous carbohydrates & 140.90 & 640.9 & 161.90 \\
Gross energy (Mcal/kg) & 3.66 & 4.45 & 4.64 \\
Sodium & 61.30 & 0.30 & 2.20 \\
Chloride & 75.10 & 0.40 & 0.80 \\
Phosphorus & 4.80 & 6.70 & 8.00 \\
Calcium & 7.70 & 1.10 & 4.70 \\
Magnesium & 3.40 & 1.20 & 5.30 \\
Potassium & 14.00 & 8.00 & 27.20 \\
\hline
\end{tabular}

${ }^{a}$ Neutral detergent fiber corrected for ash and protein.

The metabolism trial was started 30 days after the beginning of the performance trial, using 24 of the same animals. Lambs were housed in individual metabolic cages equipped with feeder, drinker, and salt trough, located in a covered area. Because the animals were already adapted to the experimental diets, a period of only seven days was used for the new adaptation to cages, and four days for total collection of feces and urine. After the metabolism trial, animals were returned to their stalls for the resumption of the performance trial. Feces were collected twice daily, weighed, and sampled (10\% 
of the total excreted), and a composite sample from each animal was obtained at the end of the collection period for chemical analyses. Urine was harvested and weighed once daily in plastic buckets containing $100 \mathrm{~mL}^{-1} 2 \mathrm{~N}$ hydrochloric acid to prevent nitrogen losses by volatilization. Additionally, urine was sampled $(10 \%$ of the total excreted) for determination of the nitrogen content.

The intakes of drinking water and mineral salt were recorded individually, and so was evaporation from the two buckets of water distributed strategically in the shed, aiming to correct the water losses from evaporation. The water was weighed daily, and the mineral salt — provided in a separate trough — was weighed on the first and last days of collections of feces and urine. Intake was calculated as the difference between the amount provided and the leftovers. Water balance was also calculated, based on the determination of all water sources (drinking water, water from the feed, and metabolic water) and all water losses (urine, feces, and insensible losses). Metabolic water production was estimated from the chemical analysis of the diets and calculated by multiplying the intakes of digestible carbohydrates, protein, and ether extract by the factors $0.60,0.42$, and 1.10 , respectively (TAYLOR et al., 1969; CHURCH, 1976). Insensible losses were calculated by subtracting the water lost via feces and urine by the total water input (drinking water + water from the feed + metabolic water) (CHURCH, 1976).

The dry matter (DM), organic matter (OM), crude protein $(\mathrm{CP})$, and mineral matter (MM) contents were determined in the samples of feeds supplied, leftovers, and feces according to methods described by Silva and Queiroz (2006). Ether extract (EE) was determined in an Ankom XT-10 extractor (Ankom Technology). Neutral detergent fiber corrected for ash and protein (NDFap), acid detergent fiber (ADF), and lignin were obtained according to Van Soest et al. (1991), using non-woven fabric bags $\left(\mathrm{TNT}-100 \mathrm{~g} / \mathrm{m}^{2}\right)$. Total carbohydrates (TC) were obtained by the following equation: $100-(\% \mathrm{CP}+$
$\% \mathrm{EE}+\% \mathrm{MM}$ ), while non-fibrous carbohydrates (NFC) were determined as the difference between TC and NDFap, proposed by Sniffen et al. (1992). The total digestible nutrients (TDN) were calculated as recommended by Weiss (1999), as follows: $\mathrm{TDN}=$ digestible $\mathrm{CP}+2.25 \times$ digestible $\mathrm{EE}+$ digestible NDFap + digestible NFC. The minerals phosphorus, chloride, sodium, calcium, magnesium, and potassium were also determined after nitric-perchloric digestion of samples of the feeds supplied. Chloride and phosphorus were determined by spectrophotometry, and the others were obtained by atomic absorption.

Nutrient intake was calculated as the difference between the amount of a nutrient present in the feeds provided and the amount of the nutrient or mineral present in the leftovers. The apparent digestibility coefficients of each nutrient and absorption coefficients of each mineral were calculated by the following formula: apparent digestibility or absorption coefficient $(\%)=[$ Nutrient or mineral intake $(\mathrm{g})$ - nutrient or mineral excreted in feces $(\mathrm{g}) /$ Nutrient or mineral intake $(\mathrm{g})] \times 100$. Density and total nitrogen were determined in the urine samples. The apparent nitrogen balance (NB) was calculated by following the methodology described by Silva and Leão (1979), expressed in $\mathrm{g} / \mathrm{day}^{-1}$ and in $\mathrm{g} / \mathrm{kg}^{0.75} /$ day $^{-1}$, which considers the following formulae: NB or $\mathrm{N}_{\text {retained }}=\mathrm{N}_{\text {intake }}-\left(\mathrm{N}_{\text {feces }}+\mathrm{N}_{\text {urine }}\right) ; \mathrm{N}_{\text {absorbed }}=\mathrm{N}_{\text {intake }}-$ $\mathrm{N}_{\text {feces }}$; and $\mathrm{N}_{\text {intake }}=\mathrm{N}_{\text {supplied }}-\mathrm{N}_{\text {leftovers. }}$

A completely randomized experimental design with four treatments and eight replicates was employed. Results were evaluated by regression analysis, in which the degrees of freedom were decomposed into linear effect, according to the percentages of old man saltbush. The significance of regressions was obtained by the " $\mathrm{t}$ " test, using SAS statistical software (SAS, 2002).

\section{Results and Discussion}

Only the intakes of mineral matter (MM) and acid detergent fiber (ADF) increased and the intakes 
of ether extract (EE) and non-fibrous carbohydrates (NFC) decreased as the inclusion of old man saltbush in the diet was elevated (Table 3). It can be inferred that, because the dry matter intake did not changed, the increase or reduction of the analytical fraction in the dry matter of the experimental diets explains the increments in DM and ADF intakes and reductions in EE and NFC.

Table 3. Nutrient intake by lambs fed diets containing old man saltbush hay.

\begin{tabular}{|c|c|c|c|c|c|c|}
\hline \multirow{2}{*}{ Item } & \multicolumn{4}{|c|}{ Old man saltbush $\left(\mathrm{g} / \mathrm{kg}^{-1}\right)$} & \multirow{2}{*}{$\frac{\text { P-value }}{\text { Linear }}$} & \multirow{2}{*}{$\mathrm{CV}(\%)^{1}$} \\
\hline & 300 & 400 & 500 & 600 & & \\
\hline \multicolumn{7}{|c|}{ Dry matter } \\
\hline $\mathrm{g} /$ day $^{-1}$ & 1214.10 & 1277.60 & 1230.20 & 1156.00 & 0.512 & 16.12 \\
\hline $\mathrm{g} / \mathrm{kg}^{0.75}$ & 97.45 & 104.20 & 103.97 & 100.97 & 0.699 & 15.22 \\
\hline$\% \mathrm{LW}$ & 4.21 & 4.53 & 4.57 & 4.49 & 0.466 & 16.05 \\
\hline \multicolumn{7}{|c|}{ Organic matter } \\
\hline $\bar{g} /$ day $^{-1}$ & 1295.60 & 1242.80 & 1270.10 & 1151.90 & 0.193 & 15.65 \\
\hline $\mathrm{g} / \mathrm{kg}^{0.75}$ & 103.98 & 100.51 & 107.35 & 101.68 & 0.764 & 14.74 \\
\hline \multicolumn{7}{|c|}{ Mineral matter } \\
\hline $\mathrm{g} /$ day $^{-1(2)}$ & 85.19 & 103.97 & 116.97 & 137.92 & 0.000 & 19.76 \\
\hline $\mathrm{g} / \mathrm{kg}^{0.75(3)}$ & 6.83 & 8.49 & 9.86 & 12.03 & 0.000 & 18.89 \\
\hline \multicolumn{7}{|c|}{ Ether extract } \\
\hline $\mathrm{g} /$ day $^{-1(4)}$ & 52.70 & 52.03 & 45.57 & 37.30 & 0.000 & 14.49 \\
\hline $\mathrm{g} / \mathrm{kg}^{0.75(5)}$ & 4.23 & 4.24 & 3.84 & 3.25 & 0.002 & 12.25 \\
\hline \multicolumn{7}{|c|}{ Crude protein } \\
\hline $\mathrm{g} /$ day $^{-1}$ & 162.69 & 186.59 & 182.04 & 172.20 & 0.724 & 17.19 \\
\hline $\mathrm{g} / \mathrm{kg}^{0.75}$ & 13.06 & 15.21 & 15.37 & 15.05 & 0.164 & 15.86 \\
\hline \multicolumn{7}{|c|}{ Neutral detergent fiber } \\
\hline $\mathrm{g} /$ day $^{-1}$ & 494.96 & 560.72 & 587.94 & 585.28 & 0.129 & 17.14 \\
\hline $\mathrm{g} / \mathrm{kg}^{0.75(6)}$ & 39.73 & 45.78 & 49.79 & 51.17 & 0.017 & 17.04 \\
\hline \multicolumn{7}{|c|}{ Acid detergent fiber } \\
\hline $\mathrm{g} /$ day $^{-1(7)}$ & 232.39 & 278.83 & 311.52 & 316.61 & 0.009 & 19.09 \\
\hline $\mathrm{g} / \mathrm{kg}^{0.75(8)}$ & 18.65 & 22.75 & 26.38 & 27.67 & 0.001 & 18.65 \\
\hline \multicolumn{7}{|c|}{ Total carbohydrates } \\
\hline $\bar{g} /$ day $^{-1}$ & 1057.60 & 1087.80 & 1033.10 & 940.60 & 0.198 & 15.62 \\
\hline $\mathrm{g} / \mathrm{kg}^{0.75}$ & 84.88 & 88.72 & 87.35 & 82.22 & 0.784 & 14.86 \\
\hline \multicolumn{7}{|c|}{ Non-fibrous carbohydrates } \\
\hline$\overline{\mathrm{g} / \text { day }^{-1(9)}}$ & 562.60 & 527.07 & 445.15 & 355.35 & 0.000 & 14.96 \\
\hline $\mathrm{g} / \mathrm{kg}^{0.75(10)}$ & 45.15 & 42.94 & 37.56 & 31.06 & 0.000 & 13.33 \\
\hline
\end{tabular}

${ }^{1} \mathrm{CV}=$ coefficient of variation; ${ }^{2} \mathrm{Y}=37.61+1.65 \mathrm{x} . \mathrm{R}^{2}=0.92 ;{ }^{3} \mathrm{Y}=1.81+0.17 \mathrm{x} . \mathrm{R}^{2}=0.98 ;{ }^{4} \mathrm{Y}=71.41-0.54 \mathrm{x} . \mathrm{R}^{2}=0.93 ;{ }^{5} \mathrm{Y}=5.41-$ $0.03 \mathrm{x} . \mathrm{R}^{2}=0.83 ;{ }^{6} \mathrm{Y}=29.33+0.40 \mathrm{x} . \mathrm{R}^{2}=0.99 ;{ }^{7} \mathrm{Y}=155.14+2.99 \mathrm{x} . \mathrm{R}^{2}=0.98 ;{ }^{8} \mathrm{Y}=9.53+0.33 \mathrm{x} . \mathrm{R}^{2}=0.91 ;{ }^{9} \mathrm{Y}=793.61-7.05 \mathrm{x} . \mathrm{R}^{2}=$ 0.97 ; and ${ }^{10} \mathrm{Y}=60.53-0.46 \mathrm{x} . \mathrm{R}^{2}=0.91$.

The increased intake of the mineral and fibrous components (NDF and ADF) is recurrent in studies with shrubby halophytes (NORMAN et al., 2013), due to the high salt and stem contents of these forages. In the current study, the increases in ADF and reduction of NFC intakes are consistent with the elevation of the roughage:concentrate ratio of the experimental diets (LIU et al., 2005; TRIPATHI et al., 2007).

Souza et al. (2004) evaluated exclusive intake of old man saltbush and reported intakes of 30.34 and $77.32 \mathrm{~g} / \mathrm{kg}^{0.75} / \mathrm{day}^{-1} \mathrm{DM} ; 2.21$ and $6.20 \mathrm{~g} / \mathrm{kg}^{0.75} /$ day $^{-1} \mathrm{CP}$; and 13.61 and $34.30 \mathrm{~g} / \mathrm{kg}^{0.75} / \mathrm{day}^{-1} \mathrm{NDF}$ by mixed-breed goats and sheep, respectively. All 
of these values were lower than those found in the present study, probably due to the differences in the intake capacity and weight of the animals. Comparing the intake of diets containing $50 \%$ old man saltbush and $50 \%$ spineless cactus by goats and sheep, Alves et al. (2007) observed differences in the intakes of DM, CP, MM, NDF, ADF, and water, and sheep showed higher intake than goats for all the aforementioned nutrients.

The digestibility of dry matter and other nutrients, except for non-fibrous carbohydrates, was influenced as old man saltbush was included in the diet (Table 4). The reduction of the digestibility of dry matter and of most nutrients can be attributed to the increase in the roughage:concentrate ratio of the diet (CAMILO et al., 2012). The increase in the inclusion of old man saltbush from 30 to $60 \%$ in the experimental diets elevated the NDF, ADF, and lignin contents by $12.38,10.56$, and $3.78 \%$, respectively, but reduced the NFC content by $14.27 \%$. Alves et al. (2003) studied the energy contents of diets for Santa Inês lambs and observed a high and negative correlation $\left(\mathrm{r}^{2}=0.98\right)$ between the percentages of NDF and the apparent digestibility of DM. It can be inferred that the increased percentage of fibrous carbohydrates in ruminant diets is associated with the longer colonization time, reduced formation of biofilm, and reduced microbial yield (DOREAU et al., 2003; LIU et al., 2005).

Table 4. Digestibility (\%) of nutrients by lambs fed diets containing old man saltbush hay.

\begin{tabular}{lccccccc}
\hline \multirow{2}{*}{ Item } & \multicolumn{4}{c}{ Old man saltbush $\left(\mathrm{g} / \mathrm{kg}^{-1}\right)$} & & P-value & \multirow{2}{*}{$\mathrm{CV}(\%)^{1}$} \\
\cline { 2 - 4 } & 300 & 400 & 500 & 600 & & Linear & \\
\hline $\mathrm{DM}^{2}$ & 67.82 & 66.28 & 58.82 & 56.97 & & 0.000 & 6.36 \\
$\mathrm{OM}^{3}$ & 71.75 & 69.99 & 63.00 & 59.99 & & 0.000 & 5.8 \\
$\mathrm{EE}^{4}$ & 80.29 & 79.41 & 72.14 & 71.21 & & 0.002 & 7.77 \\
$\mathrm{CP}^{5}$ & 64.74 & 69.70 & 66.74 & 72.23 & & 0.041 & 6.94 \\
$\mathrm{NDF}^{6}$ & 54.95 & 51.56 & 45.59 & 41.51 & & 0.000 & 9.65 \\
$\mathrm{ADF}^{7}$ & 38.67 & 34.98 & 29.20 & 25.59 & & 0.000 & 23.88 \\
$\mathrm{TC}^{8}$ & 71.80 & 69.13 & 61.60 & 57.20 & & 0.000 & 6.13 \\
NFC & 86.62 & 87.83 & 82.49 & 82.83 & & 0.161 & 6.7 \\
\hline
\end{tabular}

${ }^{1} \mathrm{CV}=$ coefficient of variation; ${ }^{2} \mathrm{Y}=79.97-0.38 \mathrm{x} . \mathrm{R}^{2}=0.83 ;{ }^{3} \mathrm{Y}=84.56-0.40 \mathrm{x} . \mathrm{R}^{2}=0.85 ;{ }^{4} \mathrm{Y}=92.69-0.38 \mathrm{x} . \mathrm{R}^{2}=1.08 ;{ }^{5} \mathrm{Y}=59.48$ $+0.20 x . R^{2}=0.59 ;{ }^{6} Y=68.05-0.42 x . R^{2}=0.81 ;{ }^{7} Y=52.40-0.45 x . R^{2}=0.99$; and ${ }^{8} Y=87.18-0.48 x . R^{2}=0.86$.

Only the digestibility of CP increased $(\mathrm{P}<0.05)$ with inclusion of old man saltbush in the diet, which corroborates Ben Salem et al. (2010) and Araújo (2011), who stated that the high solubility of nitrogen from old man saltbush may be the cause of the increased $\mathrm{CP}$ digestibility reported in many studies evaluating this roughage. Studying increasing inclusion levels of Atriplex amnicola and Avena sativa in the diet of Merino feedlot lambs, Mahipala et al. (2009) reported that Atriplex inclusion increased the $\mathrm{CP}$ digestibility linearly, and the highest value for this variable was obtained at the highest percentage of Atriplex in the diet.
The composition of diets affected the intakes of digestible DM, OM, EE, TC, and NFC; higher levels of old man saltbush in the diet led to a decrease in the intake of these nutrients (Table 5). The digestible nutrient intake better represents the availability of each nutrient consumed by the animals, as it depicts the interaction between intake and digestibility simultaneously.

The growing inclusion of old man saltbush caused a marked decline $\left(242 \mathrm{~g} / \mathrm{day}^{-1}\right)$ in digestible organic matter (DOM) intake; this is the main factor responsible for the reduction in the uptake of digestible energy from the diets with high levels 
of Atriplex. The decline in DOM intake is likely associated with the high salt content in the dry matter of the halophyte and the $191 \mathrm{~g}$ decrease in digestible NFC intake (FIMBRES et al., 2002). As regards the nitrogen balance, there was a reduction $(\mathrm{P}<0.05)$ in the amount excreted in the urine and an increase $(\mathrm{P}<0.01)$ in the nitrogen absorbed and retained as the inclusion of old man saltbush in the animal diets was increased (Table 6).

Table 5. Digestible intake $\left(\mathrm{g} / \mathrm{day}^{-1}\right)$ of nutrients by lambs fed diets containing old man saltbush hay.

\begin{tabular}{|c|c|c|c|c|c|c|}
\hline \multirow{2}{*}{ Item } & \multicolumn{4}{|c|}{ Old man saltbush $\left(\mathrm{g} / \mathrm{kg}^{-1}\right)$} & \multirow{2}{*}{$\begin{array}{l}\text { P-value } \\
\text { Linear }\end{array}$} & \multirow{2}{*}{ CV $(\%)$} \\
\hline & 300 & 400 & 500 & 600 & & \\
\hline$\overline{\mathrm{DM}^{2}}$ & 824.07 & 843.42 & 726.37 & 655.87 & 0.018 & 17.53 \\
\hline $\mathrm{OM}^{3}$ & 930.03 & 936.54 & 802.06 & 687.29 & 0.002 & 16.55 \\
\hline $\mathrm{EE}^{4}$ & 42.35 & 41.12 & 32.79 & 26.65 & 0.000 & 16.73 \\
\hline $\mathrm{CP}$ & 105.54 & 129.68 & 120.71 & 124.43 & 0.259 & 18.82 \\
\hline NDF & 272.41 & 187.59 & 272.85 & 238.55 & 0.251 & 20.18 \\
\hline $\mathrm{ADF}$ & 90.10 & 96.85 & 97.97 & 78.28 & 0.462 & 27.72 \\
\hline $\mathrm{TC}^{5}$ & 759.53 & 749.32 & 639.20 & 534.60 & 0.000 & 16.59 \\
\hline $\mathrm{NFC}^{6}$ & 487.12 & 461.74 & 366.36 & 295.92 & 0.000 & 16.95 \\
\hline
\end{tabular}

${ }^{1} \mathrm{CV}=$ coefficient of variation; ${ }^{2} \mathrm{Y}=1042.17-6.22 \mathrm{x} . \mathrm{R}^{2}=0.83 ;{ }^{3} \mathrm{Y}=1227.19-8.63 \mathrm{x} . \mathrm{R}^{2}=0.83 ;{ }^{4} \mathrm{Y}=60.68-0.55 \mathrm{x} . \mathrm{R}^{2}=0.93 ;{ }^{5} \mathrm{Y}=$ $1024.01-7.85 x . R^{2}=0.91$; and ${ }^{6} \mathrm{Y}=703.83-6.69 x . \mathrm{R}^{2}=0.95$.

Table 6. Nitrogen balance in lambs fed diets containing old man saltbush hay.

\begin{tabular}{|c|c|c|c|c|c|c|}
\hline \multirow{2}{*}{ Item } & \multicolumn{4}{|c|}{ Old man saltbush $\left(\mathrm{g} / \mathrm{kg}^{-1}\right)$} & \multirow{2}{*}{$\begin{array}{c}\text { P-value } \\
\text { Linear }\end{array}$} & \multirow{2}{*}{$\mathrm{CV}(\%)^{1}$} \\
\hline & 300 & 400 & 500 & 600 & & \\
\hline \multicolumn{7}{|l|}{$\mathrm{N}$ intake } \\
\hline $\mathrm{g} /$ day $^{-1}$ & 22.63 & 26.08 & 25.55 & 24.33 & 0.591 & 18.59 \\
\hline $\mathrm{g} / \mathrm{kg}^{0.75} /$ day $^{-1}$ & 1.82 & 2.13 & 2.16 & 2.13 & 0.149 & 17.07 \\
\hline \multicolumn{7}{|l|}{$\mathrm{N}$ feces } \\
\hline $\mathrm{g} /$ day $^{-1}$ & 9.76 & 9.88 & 10.77 & 7.82 & 0.397 & 32.59 \\
\hline $\mathrm{g} / \mathrm{kg}^{0.75} / \mathrm{day}^{-1}$ & 0.78 & 0.80 & 0.92 & 0.68 & 0.733 & 34.21 \\
\hline$\%$ Nint & 43.58 & 37.77 & 40.73 & 31.98 & 0.046 & 21.44 \\
\hline \multicolumn{7}{|l|}{$\mathrm{N}$ urine } \\
\hline${\mathrm{g} / \mathrm{day}^{-1(2)}}$ & 10.69 & 9.50 & 8.18 & 8.35 & 0.022 & 20.35 \\
\hline $\mathrm{g} / \mathrm{kg}^{0.75} / \mathrm{day}^{-1(3)}$ & 0.86 & 0.77 & 0.68 & 0.73 & 0.041 & 16.09 \\
\hline$\% \operatorname{Nint}^{(4)}$ & 45.19 & 36.05 & 33.09 & 34.95 & 0.007 & 16.68 \\
\hline \multicolumn{7}{|l|}{$\mathrm{N}$ absorbed } \\
\hline $\mathrm{g} /$ day $^{-1}$ & 12.87 & 16.21 & 14.78 & 16.51 & 0.116 & 21.03 \\
\hline $\mathrm{g} / \mathrm{kg}^{0.75} / \mathrm{day}^{-1(5)}$ & 1.03 & 1.32 & 1.23 & 1.44 & 0.010 & 17.65 \\
\hline \multicolumn{7}{|l|}{$\mathrm{N}$ retained (NB) } \\
\hline $\mathrm{g} / \mathrm{day}^{-1(6)}$ & 2.64 & 6.71 & 6.60 & 8.16 & 0.000 & 32.86 \\
\hline $\mathrm{g} / \mathrm{kg}^{0.75} / \mathrm{day}^{-1(7)}$ & 0.21 & 0.55 & 0.55 & 0.71 & 0.000 & 31.88 \\
\hline$\% \mathrm{~N}$ ing ${ }^{(8)}$ & 11.23 & 26.18 & 26.20 & 33.06 & 0.000 & 26.46 \\
\hline $\mathrm{N}$ ret/ $\mathrm{N}$ abs ${ }^{(9)}$ & 0.19 & 0.42 & 0.44 & 0.49 & 0.007 & 19.50 \\
\hline $\mathrm{N}$ ret/ $\mathrm{N}$ int ${ }^{(10)}$ & 0.11 & 0.26 & 0.26 & 0.33 & 0.000 & 26.48 \\
\hline
\end{tabular}


When the speed of rumen protein degradation exceeds the speed of use of the nitrogen compounds for microbial protein synthesis, the excess ammonia produced in the rumen crosses the rumen wall and can be lost in urine in the form of urea (TUFARELLI et al., 2009). Considering that higher percentages of concentrate in the diet result in a faster degradation and production of ammonia in the rumen, mainly due to the higher urea contents, this excess ammonia might have contributed with the higher nitrogen losses via urine in the animals consuming more concentrate. Besides, approximately $50 \%$ of the nitrogen from old man saltbush is non-protein (NPN) and is associated with nitrates, betaine, and proline (PEARCE et al., 2010), which in turn are not used by the rumen microorganisms to their maximum, leading to increased ammonia production.
There was an effect $(\mathrm{P}<0.05)$ of old man saltbush hay inclusion only for metabolic water production, expressed in $\mathrm{mL} / \mathrm{day}^{-1}$ and in $\mathrm{g} / \mathrm{kg}^{0.75}$, and for the water derived from the feed, when expressed in $\mathrm{mL} /$ day $^{-1}$ (Table 7). Considering that the intakes of digestible EE and TC were influenced, possibly by the hay inclusion in the diet (Table 3), the metabolic water production probably followed this assumption, having its participation reduced in the input of water consumed by the animals fed diets with more hay. It is noteworthy that the intake of water from the water supply was not influenced $(\mathrm{P}<0.05)$ by inclusion of Atriplex hay. This result contrasts with those reported by Ben Salem et al. (2010), who asserted increases in water intake are recurrent in research with Atriplex and stressed that this can be considered one of the greatest restrictions to the use of old man saltbush in arid and semi-arid regions (BEN SALEM et al., 2010).

Table 7. Water balance in lambs fed diets containing old man saltbush hay.

\begin{tabular}{|c|c|c|c|c|c|c|}
\hline \multirow{2}{*}{ Item } & \multicolumn{4}{|c|}{ Old man saltbush $\left(\mathrm{g} / \mathrm{kg}^{-1}\right)$} & \multirow{2}{*}{$\begin{array}{c}\text { P-value } \\
\text { Linear }\end{array}$} & \multirow{2}{*}{ CV $(\%)$} \\
\hline & 300 & 400 & 500 & 600 & & \\
\hline \multicolumn{7}{|c|}{ Water sources } \\
\hline Metabolic $\left(\mathrm{mL} / \mathrm{d}^{-1}\right)^{2}$ & 558.95 & 558.01 & 475.88 & 403.30 & 0.001 & 16.42 \\
\hline Metabolic $\left(\mathrm{g} / \mathrm{kg}^{0.75}\right)^{3}$ & 44.85 & 45.59 & 39.91 & 35.20 & 0.003 & 13.86 \\
\hline Feed $\left(\mathrm{mL} / \mathrm{d}^{-1}\right)^{4}$ & 166.69 & 169.22 & 156.82 & 133.76 & 0.020 & 15.61 \\
\hline Feed $\left(\mathrm{g} / \mathrm{kg}^{0.75}\right)$ & 13.37 & 13.81 & 13.24 & 11.74 & 0.134 & 14.72 \\
\hline $\operatorname{Bucket}\left(\mathrm{mL} / \mathrm{d}^{-1}\right)$ & 3852.50 & 4796.30 & 4613.10 & 4046.90 & 0.843 & 25.33 \\
\hline Bucket $\left(\mathrm{g} / \mathrm{kg}^{0.75}\right)$ & 309.24 & 393.17 & 392.33 & 350.35 & 0.468 & 25.15 \\
\hline Total $\left(\mathrm{mL} / \mathrm{d}^{-1}\right)$ & 4578.10 & 5523.50 & 5245.80 & 4583.90 & 0.904 & 23.52 \\
\hline Total $\left(\mathrm{g} / \mathrm{kg}^{0.75}\right)$ & 367.46 & 452.57 & 445.48 & 397.29 & 0.644 & 23.19 \\
\hline \multicolumn{7}{|c|}{ Water outputs } \\
\hline Feces $\left(\mathrm{mL} / \mathrm{d}^{-1}\right)$ & 780.00 & 884.80 & 1012.60 & 906.10 & 0.347 & 32.19 \\
\hline Feces $\left(\mathrm{g} / \mathrm{kg}^{0.75}\right)$ & 62.67 & 72.21 & 87.10 & 79.23 & 0.185 & 34.39 \\
\hline Urine $\left(\mathrm{mL} / \mathrm{d}^{-1}\right)$ & 1078.70 & 1752.80 & 1377.70 & 1734.10 & 0.164 & 40.78 \\
\hline Urine $\left(\mathrm{g} / \mathrm{kg}^{0.75}\right)$ & 86.67 & 143.47 & 116.16 & 147.94 & 0.077 & 37.50 \\
\hline Ins. losses $\left(\mathrm{mL} / \mathrm{d}^{-1}\right)^{\mathrm{a}}$ & 2719.50 & 2885.90 & 2855.50 & 1943.80 & 0.051 & 22.07 \\
\hline Ins. losses $\left(\mathrm{g} / \mathrm{kg}^{0.75}\right)$ & 218.12 & 236.89 & 242.21 & 170.12 & 0.181 & 23.47 \\
\hline Total $\left(\mathrm{mL} / \mathrm{d}^{-1}\right)$ & 4578.10 & 5523.80 & 5245.80 & 4583.90 & 0.904 & 23.52 \\
\hline Total $\left(\mathrm{g} / \mathrm{kg}^{0.75}\right)$ & 367.46 & 452.57 & 445.48 & 397.29 & 0.644 & 23.19 \\
\hline
\end{tabular}


Also regarding water intake, this variable was expected to be influenced by inclusion of old man saltbush in the diets, because of its high sodium and chloride composition (Table 1). However, the environmental conditions evaluated at the beginning, middle, and end of the experimental periods, such as temperature during the day (average $32.4{ }^{\circ} \mathrm{C}$ ) and relative humidity of the air (average 59\%), are directly related to water intake. This factor should be taken into account in this study, since the location where the experiment took place had high temperatures during the entire experimental period. This might have influenced the high water intake by the animals from all treatments, masking the impact of feeding on this trait (ARAÚJO et al., 2010).
The performance and feed conversion of the lambs decreased as the inclusion of old man saltbush in their diet was increased (Table 8). Even if the DM intake values are above those recommended by NRC (2007) for this category $(0.70 \mathrm{~kg} \mathrm{DM} /$ day $^{-1}$ and $3.48 \%$ LW), the animals did not manage to reach the expected daily weight gain (DWG) of $200 \mathrm{~g}$, probably because of the lower energy uptake from the diets (PAPI et al., 2011). However, although the desired performance was achieved, the animals from the treatments with $30 \%$ and $40 \%$ of inclusion of the hay in their diet showed DWG of 193 and $182 \mathrm{~g} /$ day $^{-1}$, respectively, which are close to that recommended by NRC (2007).

Table 8. Initial, final, and slaughter (SW) weights, fasting losses (\%), daily weight gain (DWG), and feed conversion (FC) of lambs fed diets containing old man saltbush hay.

\begin{tabular}{lccccccc}
\hline \multirow{2}{*}{ Item } & \multicolumn{3}{c}{ Old man saltbush $\left(\mathrm{g} / \mathrm{kg}^{-1}\right)$} & & P-value & \multirow{2}{*}{$\mathrm{CV}(\%)^{1}$} \\
\cline { 2 - 4 } & 30 & 40 & 50 & 60 & & Linear & \\
\hline Initial weight $\left(\mathrm{kg}^{-1}\right)$ & 22.47 & 21.81 & 22.01 & 22.37 & & 0.975 & 6.02 \\
Final weight $\left(\mathrm{kg}^{-1}\right)^{2}$ & 36.31 & 34.87 & 32.70 & 31.06 & & 0.016 & 13.22 \\
$\mathrm{SW}\left(\mathrm{kg}^{-1}\right)^{3}$ & 32.25 & 31.29 & 28.75 & 26.81 & & 0.005 & 13.23 \\
$\mathrm{FL}(\%)^{4}$ & 11.14 & 10.03 & 12.23 & 13.76 & & 0.045 & 25.98 \\
DWG $\left(\mathrm{g} / \mathrm{day}^{-1}\right)^{5}$ & 193.41 & 181.81 & 149.31 & 120.80 & & 0.004 & 31.85 \\
FC $^{6}$ & 6.70 & 7.85 & 8.59 & 10.29 & & 0.007 & 28.19 \\
\hline
\end{tabular}

${ }^{1} \mathrm{CV}=$ coefficient of variation; ${ }^{2} \mathrm{Y}=41.79-0.18 \mathrm{x} . \mathrm{R}^{2}=0.99 ;{ }^{3} \mathrm{Y}=38.26-0.19 \mathrm{x} . \mathrm{R}^{2}=0.97 ;{ }^{4} \mathrm{Y}=7.26+0.10 \mathrm{x} . \mathrm{R}^{2}=0.66 ;{ }^{5} \mathrm{Y}=273.98$ $-2.50 x . R^{2}=0.96$; and ${ }^{6} \mathrm{Y}=3.16+0.11 \mathrm{x} . \mathrm{R}^{2}=0.96$.

Souto et al. (2005) also observed a reduction in the DWG of sheep fed diets including old man saltbush, in which the highest inclusion level $(83.7 \%)$ caused the lowest gain, $69 \mathrm{~g} / \mathrm{day}^{-1}$. Ben Salem et al. $(2004,2005)$ studied the use of old man saltbush in the feeding of sheep and reported that the low energy content in its composition and the high salt content of its leaves are related to reduced intake and nutrient digestion, which negatively affects the animal performance. Based on these assumptions, it is noted that the low performance of the animals in this study, especially as the level of old man saltbush in the diet was increased (Table
1), was also likely due to the low energy content, which did not reach the minimum of $660 \mathrm{~g} / \mathrm{kg}^{-1}$ recommended by NRC (2007) for performance of lambs in the daily weight gain range evaluated here.

\section{Conclusions}

Inclusion of old man saltbush at up to $40 \%$ in the diet of feedlot lambs does not compromise the performance of these animals. As such, old man saltbush can be used as a good alternative source of nutrients. 


\section{References}

AGUDELO, J. C. C. Efecto de la utilización de arbóreas y arbustivas forrajeras sobre a dinâmica digestiva em bovinos. Revista Lasallista de Investigación, Antioquia, v. 4, n. 1, p. 39-50, 2007.

ALVES, J. N.; ARAÚJO, G. G. L.; PORTO, E. R.; CASTRO, J. M. C.; SOUZA, L. C. Feno de ervasal (Atriplex nummularia Lindl.) e palma forrageira (Opuntia ficus Mill.) em dietas para caprinos e ovinos. Revista Científica de Produção Animal, Teresina, v. 9, n. 1, p. 43-52, 2007.

ALVES, K. S.; CARVALHO, F. F. R.; VÉRAS, A. S. C.; FERREIRA, M. A.; COSTA, R. G.; SANTOS, E. P.; FREITAS, C. R. G.; SANTOS JÚNIOR, C. M.; ANDRADE, D. K. B. Níveis de energia em dietas para ovinos Santa Inês: digestibilidade aparente. Revista Brasileira de Zootecnia, Viçosa, MG, v. 32, n. 6, p. 19621968, 2003.

ARAÚJO, G. G. L. Utilização de forrageiras halófitas na alimentação de pequenos ruminantes: o potencial da erva-sal (Atriplex nummularia Lindl). In: CONGRESSO BRASILEIRO DE ZOOTECNIA, 21., 2011, Maceió. Anais... Maceió: ZOOTEC, 2011. CD-ROM.

ARAÚJO, G. G. L.; VOLTOLINI, T. V.; CHIZZOTTI, M. L.; TURCO, S. H. N.; CARVALHO, F. R. C. Water and small ruminant production. Revista Brasileira de Zootecnia, Viçosa, MG, v. 39, p. 326-336, 2010. Suplemento Especial.

AREGHEORE, E. M. Nutritive and antinutritive value of some tree legumes used in ruminant livestock nutrition in Pacific island countries. Journal of South Pacific Agriculture, Samoa, v. 6, n. 2, p. 50-61, 1999.

ARIELI, A.; NAIM, E.; BENJAMIN, R. W.; PASTERNAK, D. The effect of feeding saltbush and sodium chloride on energy metabolism in sheep. Animal Production, Neston, v. 49, n. 3, p. 451-457, 1989.

BEN SALEM, H.; ABDOULI, H.; EL-MASTOURI, A.; BEN SALEM, L. Nutritive value, behaviour, and growth of Barbarine lambs fed on oldman Saltbush (Atriplex nummularia L.) and supplemented or not with barley grains or spineless cactus (Opuntia ficus-indica f. inermis) pads. Small Ruminant Research, Amsterdam, v. 59, n. 2, p. 229-237, 2005.

BEN SALEM, H.; NEFZAOUI, A.; BEN SALEM, L. Spineless cactus (Opuntia fícus indica f. inermis) and oldman saltbush (Atriplex nummularia L.) as alternative suplements for growing Barbine lambs given strawbased diets. Small Ruminant Research, Amsterdam, v. 51, n. 1, p. 65-73, 2004.
BEN SALEM, H.; NORMAN, H. C.; NEFZAOUI, A.; MAYBERRY, D. E.; PEARCE, K. L.; REVELL, D. K. Potential use of oldman saltbush (Atriplex nummularia Lindl.) in sheep and goat feeding. Small Ruminant Research, Amsterdam, v. 91, n. 1, p. 13-28, 2010.

CAMILO, D. A.; PEREIRA, E. S.; PIMENTEL, P. G.; OLIVEIRA, R. L.; CÂNDIDO, M. J .D.; COSTA, M. R. G. F.; AQUINO, R. M. S. Intake and feeding behaviour of Morada Nova lambs fed different energy levels. Italian Journal of Animal Science, Pavia, v. 11, p.13-19, 2012.

CHURCH, D. C. Digestive physiology and nutrition of ruminants: digestive physiology. $2^{\text {th }}$ ed. Corvallis: O \& B Books Publishing, 1976. 349 p.

DOREAU, M.; MICHALET-DOREAU, B.; GRIMAUD, P.; ATTI, N.; NOZIÈRE, P. Consequences of underfeeding on digestion and absorption in sheep. Small Ruminant Research, Amsterdam, v. 49, n. 3, p. 289-301, 2003.

FIMBRES, H.; KAWAS, J. R.; HERNÁNDEZ-VIDAL, G.; PICÓN-RUBIO, J. F.; LU, C. D. Nutrient intake, digestibility, mastication and ruminal fermentation of lambs fed finishing ration with various forage levels. Small Ruminant Research, Amsterdam, v. 43, n. 3, p. 275-281, 2002.

FOOD AND AGRICULTURAL ORGANIZATION FAO. Atriplex nummularia Lindl.: una especie pionera para las zonas aridas de Chile. In: OFICINA REGIONAL DE LA FAO PARA AMÉRICA LATINA Y EL CARIBE, 10., 1996, Santiago. Anales... Santiago: FAO, 1996. p. 111-141.

FRANCOTE, C. R.; NORMAN, H. C.; WILLIAMS, I. H.; MASTERS, D. G. Cattle performed as well as sheep when grazing a river saltbush (Atriplex amnicola)-based pasture. Animal Production Science, Amsterdam, v. 49, n. 11, p. 998-1006, 2009.

LIU, X.; WANG, Z.; LEE, F. Influence of concentrate level on dry matter intake, $\mathrm{N}$ balance, nutrient digestibility, ruminal outflow rate, and nutrient degradability in sheep. Small Ruminant Research, Amsterdam, v. 60, n. 1, p. 4552, 2005.

MAHIPALA, M. B. P. K.; KREBS, G. L.; McCAFFERTY, P.; DODS, K. Effects of increasing the inclusion level of Atriplex amnicola in the diet of sheep. Animal Production Science, Amsterdam, v. 49, n. 11, p. 1029-1034, 2009.

McDONALD, P.; EDWARDS, R. A.; GREENHALGH, J. F. D.; MORGAN, C. A. Animal nutrition. $6^{\text {th }}$ ed. Harlow: Pearson Education, 2002. 693 p.

MEDEIROS, S. R.; MARINO, C. T. Proteínas na nutrição de bovinos de corte. In: MEDEIROS, S. R.; GOMES, R. C.; BUNGENSTAB, D. J. Nutrição de bovinos de 
corte: fundamentos e aplicações. Brasília: EMBRAPA/ SENAR, 2015. p. 29-44.

NATIONAL RESEARCH COUNCIL - NRC. Nutrients requirements of sheep. Washington: National Academies Press, 2007. 362 p.

NORMAN, H. C; MASTERS, D. G.; BARRETTLENNARD, E .G. Halophytes as forages in saline landscapes: interactions between plant genotypes and environment change their feeding value to ruminants. Environmental and Experimental Botany, Amsterdam, v. 92, p. 96-109, 2013.

OTAL, J.; ORENGO, J.; QUILES, A.; HEVIA, M. L.; FUENTES, F. Characterization of edible biomass of Atriplex halimus L. and its effect on feed and water intakes, and on blood mineral profile in non-pregnant Manchega-breed sheep. Small Ruminant Research, Amsterdam, v. 91, n. 2 e 3, p. 208-214, 2010.

PAPI, N.; MOSTAFA-TEHRANI, A.; AMANLOU, H.; MEMARIAN, M. Effects of dietary forage-to-concentrate ratios on performance and carcass characteristics of growing fat-tailed lambs. Animal Feed Science and Technology, Amsterdam, v. 163, n. 2-4, p. 93-98, 2011.

PEARCE, K. L.; NORMA, H. C.; HOPKINS, D. L. The hole of saltbush-based pasture systems for the production of high quality sheep and goat meat. Small Ruminant Research, Amsterdam, v. 91, n. 1, p. 29-38, 2010.

POTTER, B. J. The renal response of sheep to prolonged ingestion of sodium chloride. Australian Journal of Agricultural Research, Oxford, v. 12, n. 3, p. 440-445, 1961.

STATISTICAL ANALYSIS SYSTEM INSTITUTE - SAS. User's guide release. Cary: SAS Institute Inc., 2002.

SILVA, D. J. S.; QUEIROZ, A. C. Análise de alimentos: métodos químicos e biológicos. 3. ed. Viçosa, MG: Editora UFV, 2006. 235 p.

SILVA, J. F.; LEÃO, M. I. Fundamentos de nutrição de ruminantes. Piracicaba: Livroceres, 1979. 380 p.

SNIFFEN, C. J.; O’CONNOR, J. D.; VAN SOEST, P. J.; FOX, D. G.; RUSSELL, J. B. A net carbohydrate and protein system for evaluating catlle diets: II. Carbohydrate and protein availability. Journal of Animal Science, Savoy, v. 70, n. 11, p. 3562-3577, 1992.

SOUTO, J. C. R.; ARAÚJO, G. G. L.; MOREIRA, J. N.; SILVA, D. S.; COSTA, R. G.; PORTO, E. R. Consumo e digestibilidade aparente de nutrientes em dietas para ovinos. com diferentes níveis de feno de erva-sal (Atriplex nummularia Lindl.). Revista Ciência Agronômica, Fortaleza, v. 35, n. 1, p. 116-122, 2004.
SOUTO, J. C. R.; ARAÚJO, G. G. L.; SILVA, D. S.; COSTA, R. G.; PORTO, E. R.; TURCO, S. H. N.; MEDEIROS, A. N. Desempenho produtivo de ovinos alimentados com dietas contendo níveis crescentes de feno de erva sal (Atriplex nummularia Lindl.). Revista Ciência Agronomica, Fortaleza, v. 36, n. 3, p. 376-381, 2005.

SOUZA, C. M. S.; ARAÚJO, G. G. L.; PORTO, E. R. Consumo voluntário do feno de erva-sal Atriplex nummularia Lindl. em caprinos e ovinos. In: CONGRESSO NORDESTINO DE PRODUÇÃO ANIMAL, 3., 2004, Campina Grande. Anais... Campina Grande: Sociedade Nordestina de Produção Animal, 2004. CD-ROM.

STANDING COMMITTEE ON AGRICULTURE - SCA. Feeding standards for australian livestock. Melbourne: CSIRO Publications, 1990. 226 p.

TAYLOR, C. R.; SPINAGE, C. A.; LYMAN, C. P. Water relations of the waterbuck, an East African antelope. American Journal of Physiology, Baltimore, v. 217, n. 2, p. 630-634, 1969.

TRIPATHI, M. K.; CHATURVEDI, O. H.; KARIM, S. A.; SINGH, V. K.; SISODIYA, S. L. Effect of different levels of concentrate allowances on rumen fluid $\mathrm{pH}$, nutrient digestion, nitrogen retention and growth performance of weaner lambs. Small Ruminant Research, Amsterdam, v. 72, n. 2 e 3, p. 178-186, 2007.

TUFARELLI, V.; DARIO, M.; LAUDADIO, V. Influence of dietary nitrogen sources with different ruminal degradability on growth performance of Comisana ewe lambs. Small Ruminant Research, Amsterdam, v. 81, n. 2 e 3, p. 132-136, 2009.

VAN SOEST, P. J. Nutritional ecology of the ruminant. New York: Cornell University Press, 1994. 476 p.

VAN SOEST, P. J.; ROBERTSON, J. B.; LEWIS, B. A. Methods for extraction fiber. Neutral detergent fiber and nonstarch polyssaccarides in relation to animal nutrition. Journal of Dairy Science, Savoy, v. 83, n. 1, p. 35833597, 1991.

WEISS, W. P. Energy prediction equations for ruminant feeds. In: CORNELL NUTRITION CONFERENCE FOR FEED MANUFACTURERS, 61., 1999, Ithaca. Proceedings... Ithaca: Cornell University, 1999. p. 176185. 